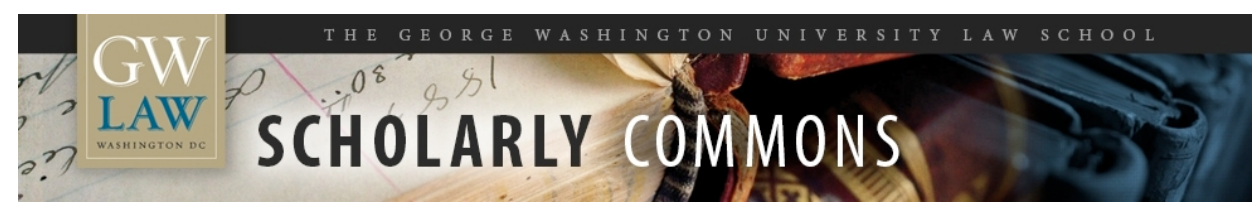

GW Law Faculty Publications \& Other Works

Faculty Scholarship

2010

\title{
The Last Days of the American Lawyer
}

Thomas D. Morgan

George Washington University Law School, tmorgan@law.gwu.edu

Follow this and additional works at: https://scholarship.law.gwu.edu/faculty_publications

Part of the Law Commons

\section{Recommended Citation}

Morgan, Thomas D., "The Last Days of the American Lawyer" (2010). GW Law Faculty Publications \& Other Works. 828.

https://scholarship.law.gwu.edu/faculty_publications/828

This Article is brought to you for free and open access by the Faculty Scholarship at Scholarly Commons. It has been accepted for inclusion in GW Law Faculty Publications \& Other Works by an authorized administrator of Scholarly Commons. For more information, please contact spagel@law.gwu.edu. 


\section{The Last Days of the American Lawyer}

\section{Thomas D. Morgan ${ }^{1}$}

\section{A. Introduction - The Golden Age is Over}

In the legal world's game of musical chairs, 2009 was the year the music stopped. For a number of years, the greatest single complaint heard from lawyers was that they had to work too hard. In 2009, however, lawyers who had been chasing more and more work at an ever faster pace found themselves suddenly looking for a secure place - almost any place - to survive the declining demand for their services. Over 4,000 lawyers - some of them equity partners - lost positions in major firms. Students all over the country have found promised jobs "deferred" until some oftenundefined future date, and many in the graduating classes of 2010 and beyond wonder if they will get any employment offers at all.

Lawyers hope the music will begin again, and it probably will, but if the predictions of this lecture are correct, the melody lawyers hear will be quite different. As has always been true, those who practice law face a world in which the demand for lawyers is determined by what clients need lawyers to do. The premise of this lecture and the book on which it is based is that lawyers are facing fundamental changes in both what they will be asked to do and how much work that lawyers once did will continue to be done by them. The world that lawyers face today, in short, may be much like the world in which they are destined to live.

When we talk about the American lawyer, the world many still imagine is that of the 1950s

\footnotetext{
${ }^{1}$ Oppenheim Professor of Antitrust and Trade Regulation Law, George W ashington University Law School.
}

This paper was prepared as the Lane Foundation Lecture at Creighton Law School on October 1, 2009. The paper is based on Thomas D. Morgan, The Vanishing Lawyer: The Ongoing Transformation of the U.S. Legal Profession (Oxford University Press, Jan. 2010) and is Copyright (C) 2009 by Thomas D. Morgan. Citations found in the book manuscript have been omitted from this lecture version. 
and 1960s, a period now sometimes called the "golden age" of the American bar. I can remember that time. Lawyers' lives were relatively stable. An associate who worked hard could expect to have senior lawyers act as mentors. The young associate would likely become a partner and would likely retire from the firm in which he began his practice. Along the way, he would have earned an above-average income, worked on a variety of cases, and been a leader in community organizations. Most lawyers did not get rich in the golden age, but Professor Mitt Regan summarizes the prevailing ethos as "nobody starves."

Lawyers are properly worried that the new world will be different. Legal regulation is not vanishing. Indeed, as society becomes more complex, the place of law in regulating conduct is likely to increase. Instead, what I predict is that the interaction of law with increasingly complex economic and social issues will make distinctively legal questions less common and make many of the skills that we stress in law schools less relevant. Rather than needing professionals whose understanding of law dwarfs their understanding of the substantive issues faced by clients, the world will require legally-trained persons to be more fully integrated into the substantive challenges tomorrow's clients face. That reality may require that more persons, not fewer, have some legal training, but the training of most people will almost certainly not be today's three year graduate program designed to produce an all-purpose legal generalist.

Today's lawyers, in turn, will not be unemployable, but for at least significant parts of their careers, they will be required to develop specialized expertise both in an area of substantive law and in the non-legal aspects of their potential clients' problems. If they fail to develop both kinds of expertise, they will find at almost every turn that clients will take their problems to those prepared to deliver what the clients need at a higher level of quality, a lower cost, or both. 


\section{B. Changes That Have Brought Us to Where We Are}

What has happened since the golden age to bring lawyers to this state of affairs? I think that the transformation of lawyers' work reality has been the result of eight important trends over the last 40 years.

First, we used to think of the legal profession as "self-regulating." Lawyers wrote the rules by which lawyers lived, and not surprisingly, we tended to write them in a way that favored ourselves. That all changed in the mid-1970s. Some of the case names are familiar. In Goldfarb v. Virginia State Bar, the United States Supreme Court in 1975 struck down a bar association's minimum fee schedule as a violation of the antitrust laws. In 1977, the Supreme Court held in Bates v. State Bar of Arizona that even a state supreme court's prohibition of lawyer advertising was a violation of the United States Constitution. Quite apart from the substance of those cases, the reality that external law governed lawyers themselves unsettled the quiet life most lawyers had enjoyed.

Second, growth in the number of lawyers over the last 40 years has greatly increased the competitive pressure on each of them. In 1970, at the end of the "golden age," there were about 300,000 lawyers in the entire country. That same year, however, about 100,000 students had enrolled in law school, and law schools have produced 40,000 or more new lawyers each year ever since. Today, the nation has about 1.2 million licensed lawyers, about 1 million of whom are in practice. With that kind of competition, it is no wonder the ability to attract business is a primary determinant for a lawyer's success.

If you want a simple picture of why today's law students are having a hard time finding jobs, you need to know that the nation's demand for new lawyers most closely tracks the rate of increase in the nation's gross domestic product. Every time the economy slows but law schools keep churning out the same number of new lawyers, we produce a lawyer surplus that does not go away. 
We had roughly $20 \%$ more lawyers than the country could fully employ before $2008-09$, but in those years we produced $4 \%$ more lawyers at the same time economic activity shrank about $6 \%$. Thus, in a single year, we added roughly another $10 \%$ surplus of lawyers nationally. If our graduates want to practice law - and many will - competition for the available work is only going to be even more intense than before. Yet the business model of most law schools makes cutting back enrollments almost unthinkable.

Third, the impact of globalization has transformed the reality of many lawyers' practices. In the 1950s and 60s, most Omaha lawyers thought of Des Moines and St. Paul as the significant "foreign" capitals. Today, an Omaha lawyer is as likely to help a client do business in Dubai or Shanghai. Instead of sometimes conflicting state laws, lawyers must deal with conflicts in whole legal systems. For a real estate lawyer, Blackacre could as easily be in London as Lincoln. Even a will drafter or family lawyer may have to protect the interests of children who are in Sydney or Sao Paulo. The complexity created by that reality of today's law practice has made it nearly impossible to be the kind of generalist we once thought of when we called someone a lawyer.

Further, in today's globalized environment, American lawyers find themselves in competition with legal service providers all over the world who operate under different rules. As a result of the Legal Services Act of 2007, for example, British lawyers now can operate in firms with non-lawyers and the attorney-client privilege extends to communication with the non-lawyers. Australian lawyers are now permitted to practice in corporate entities that sell stock to the general public, and the European Union is considering similar changes in lawyer regulation. If American lawyers ignore the fact their direct competitors play by different rules, they will have only themselves to blame when clients seek the same or better services at lower cost elsewhere. 
A fourth major factor contributing to today's lawyer reality is the revolution in computer storage and communications technology that has occurred over roughly the same 40 -year period since the lawyers' golden age. We all know the changes in legal research and in document discovery that technological developments have created. We also know technology has made lawyers' lives more hectic. Somewhere in the world, it is always daylight, and clients want lawyers always to be on call.

Most important, information technology promises to transform lawyer work that used to be seen as complex, unique and worthy of substantial fees into a set of "commodities" - simple, repetitive operations that will be provided to clients by the lowest bidder. Technology available on the simplest personal computer today can allow a lawyer to copy a 500-page document used in one transaction and change the names and terms for use in the next. Obviously, the result will be a disaster if the document is not equally relevant to the new situation, so the malpractice risk created by the ease of copying can be enormous. Knowing what changes are needed to fit a new situation will always be a big part of the professional's service, but the benefits of standardizing forms in transactions promises to transform what we used to see as creative work.

Further, and in some ways most frustrating for lawyers, is the fact that much of the information lawyers have traditionally sold is now freely available on the Internet. Books about law have been around for years, but technology now makes the information ubiquitous. Insights may be provided free at websites ranging from Wikipedia to blogs, and the effect is to render a great deal of formerly exotic legal information broadly accessible. Prepared by thousands of authors, these alternative information sources threaten the monopoly on which lawyers have depended for a steady client base. Clearly, lawyers will tend to be able to assimilate and apply such information more quickly and accurately than many clients can, but the breakthrough is that a lawyer's knowledge is 
no longer a black box incapable of client penetration. Whether the client is a corporation or an individual, clients can be expected to seek assistance from multiple sources ready to provide them using publicly-available information rather than buying assistance in a proprietary form created and sold by lawyers alone.

Fifth, and clearly related to the developments we've described, has been the growth of the size of organizations in which lawyers now practice. When I was in law school during the golden age, my dad was in the largest firm in Illinois outside Chicago. It had eleven lawyers. In 1960, less than 20 U.S. law firms had more than 50 lawyers each, and even by 1968, only 20 firms in the entire country had over 100 lawyers. I don't need to tell an Omaha audience that one of the first people to see that larger firms would win the day was Bob Kutak, who with Harold Rock opened offices in Denver, Atlanta, and Washington so as to build the first "national" law firm. Now, size leadership has passed to Baker \& McKenzie and DLA Piper that each has over 3500 lawyers. Indeed, at least 20 firms have now crossed the 1000-lawyer mark. I am not decrying law firm growth, but the all-purpose "lawyer" we remember in stories of Abraham Lincoln, Clarence Darrow and Atticus Finch, is disappearing - not likely to be seen again.

The sixth key development of the last 40 years has been the transformation of what scholars call the "hemispheres" of the bar. In 1960, sociologist Jerome Carlin reported that in New York, business lawyers made up $45 \%$ of the bar, while individual-oriented work such as personal injury, criminal, divorce, wills and real estate made up the other 55\%. Lawyers tended to work on one side or the other of the individual/business divide; but it was "people" lawyers who represented the public face of the law.

Just fifteen years later, Jack Heinz \& Edward Laumann documented the individual/ business distinction in the Chicago bar and showed that the lawyers who populated each differed in terms of 
social class, where they went to law school, how much money they made, their status as leaders of the bar, and the like. They concluded that by $1975,53 \%$ of lawyers worked on business issues (up from $45 \%$ ), while only $40 \%$ of lawyers still did work for individuals. After another two decades, in 1995, the authors concluded that the proportion of corporate lawyers had increased from 53\% to $64 \%$, while lawyers for individuals had fallen from $40 \%$ to $29 \%$. In short, less than $1 / 3$ of legal talent in this country now tries to meet the needs of individual clients.

That does not mean lawyers for individuals are unimportant. It does not even mean all such lawyers are poor. Successful plaintiffs' personal injury lawyers, for example, can earn incomes that make corporate lawyers jealous. Lawyers who help preserve pools of individual wealth similarly charge high fees. What the trends do mean, however, is that a realistic look at the legal profession reveals that the number of attractive opportunities available to lawyers who do not want to do corporate work is getting smaller and at a faster rate than ever before.

Seventh, even the growth of law firms and the shift of law practice toward corporate work pale by comparison to the rising power of in-house counsel. Thirty years ago, and in many cases much more recently, lawyers in private firms saw their role to be providing wise counsel to lay officers or employees of corporate clients. That is now much less true. The people most of today's lawyers have to please are other lawyers - this time lawyers acting in the role of general counsel to corporations, government agencies, and other organizations. In short, private law firms advise - and market their services to - corporate lawyers and it is that group - who number $10 \%$ of all lawyers - that tends to decide what outside services the client requires and why.

Recruiting in-house lawyers rather than depending exclusively on outside firms began as a way for companies to avoid high law firm billing rates and as a form of vertical integration that reduced the cost of searching for lawyers to do recurring tasks. But a strong internal lawyer staff 
also helps assure that legal service decisions are made by people who understand the client's business, know the type of legal work that is required, and are able to help managers think about the non-legal issues inherent in important business decisions. A survey of CEOs for the Corporate Counsel Association (CCA), for example, said that $93 \%$ of senior executives believe inside counsel understand the company better and $37 \%$ even say they trust inside counsel more.

Private law firms are familiar with the practice of hiring "contract lawyers," i.e., lawyers hired to do particular tasks when the firm is especially busy on a case or regulatory filing but who the firm will not need in the long run. Today, private law firms can best be understood as inside counsel's version of contract lawyers. It hurts for lawyers in private firms to realize that their practice has come to that. The firm they spent their lives building has now become the functional equivalent of a temp agency, and it hurts even more when they are beaten out for commodity work on which they used to train associates but that can be done less expensively by firms in India. There is no escaping the reality that the practice of law has become more competitive and lawyers have become more personally insecure. It is unfortunate but true that many lawyer-client relationships have become less like life-long marriages and more like one-night stands.

Eighth and finally on our list of changes driving ways the lawyer's world is transforming, the logical outcome of the growing significance of corporate counsel managing legal needs, and the world-wide availability of help with legal matters, is the declining significance of having an American law license before providing traditional legal services. One might think traditional unauthorized practice of law prohibitions will protect American lawyers' former practice areas, but as we have seen, changes ranging from globalization to the way clients get information are likely to undercut efforts to protect American lawyers against these fundamental changes. An Executive Order signed by President Clinton requires federal agencies to allow non-lawyers to counsel and 
represent clients in agency proceedings, and the effect has been both increased aid available to claimants and a decline in the number of potential claimants that rely on lawyers.

Lawyers themselves are breaking down traditional unauthorized practice barriers as they assist their clients, not only in the state in which the lawyer is licensed to practice, but in other states or nations where the client has legal needs. Law firms have long used paralegal and other support personnel nominally working under the lawyer supervision that ethical standards require. In addition, corporations now use non-lawyers to help deliver the total package of services they need done. Negotiating contracts, troubleshooting discrimination claims, even writing court documents can all be done by non-lawyers within an organization receiving a level of lawyer supervision and training to which unauthorized practice rules cannot effectively speak. Current legal ethics rules require a lawyer in a private law firm to supervise and take responsibility for the non-lawyer's work, but that requirement is easily met, and the non-lawyers are often accountants or lobbyists, economists or nurses, statisticians or business specialists who are more than capable of acting on their own.

The message that I hope comes through is that the vision of the American lawyer traditionally held out to the country by the American Bar Association is largely vanishing. Lawyers now must understand themselves in terms of the world in which they work and whose changing dynamics they cannot ignore. Ours will not become a society with no persons specially trained to deal with legal issues, but people we today call lawyers seem destined primarily to provide a form of business consulting service rather than traditional legal advice and litigation.

And lest you think this can't happen, not too many years ago, one of the most secure jobs available was that of a toll booth operator on a bridge or highway. The bridge and the road were there to stay, and cars on both had to stop at the booth and pay a toll. Lawyers were in much the 
same position; no one could safely write a contract or seek legal relief without passing the issues by a lawyer. Now, toll booths are largely empty as an electronic EZ Pass collects the tolls as cars pass by at highway speed. It will be lawyer occupational suicide if we fail to try to avoid the same fate.

\section{Implications for the Future American Lawyer}

What then will the future American lawyer do? I think that lawyers are likely to spend their career trying to stand out among a collection of diverse service providers, each offering to add more to a client's work and life than the client must pay for their service. Even if some of the providers even still call themselves lawyers, at any given time in their careers they will likely focus their work in narrow fields in which they can be known as among the best.

In principle, it still might be possible for someone with legal training and considerable free time to prepare hard enough in a new field to handle a case without committing malpractice, but the skills required to represent a client effectively will often be so multi-dimensional that few lawyers will be likely to stray far from the kinds of work they know how to perform well. Lawyers might change areas of concentration as areas of client need become obsolete or others open up, but in a stratified, globalized world in which clients have technology available to find the kind of counselor they need, each provider will have to become among the best at doing particular kinds of work that a reasonable number of clients need done.

Many traditional lawyer services to individuals will tend to be delivered as commodities, that is, as standardized products sold primarily on the basis of price. Estate planning, real estate transactions, adoptions and uncontested divorces each can present unique negotiation and human relations problems, but the legal components of the cases tend to be repetitive. Technology will allow documents for many such cases to be sold as forms or tailored to individual needs using a few clicks of a computer mouse. If a client needs face-to-face advice for reassurance, needs help in 
places to which it would be costly for the client to travel, or needs to take a matter to court, someone with legal training might become involved and provide valuable services. But for the kinds of work that many legal service providers with modest training can do quite well, competition should drive fees and lawyer incomes to levels far lower than we see today.

It is a mistake, of course, to view all cases as routine matters. Some individual clients find themselves injured and in need of compensation from persons or organizations who are not willing to pay. Others find themselves charged with crime, finding their immigration status challenged, or assessed back taxes, fines and penalties. Such clients will continue to entrust their future to legallytrained providers. Even some litigation can involve standardized templates to be sure issues are raised or defended correctly, but many who today call themselves trial lawyers will continue to find their services in demand in the years ahead.

The trend of American lawyers toward disproportionately serving organizational clients is likely to continue if only because businesses are likely to offer the most money for legal services. There, too, however, tomorrow's lawyers are likely to find themselves competing for attention against a wide range of foreign lawyers and non-lawyer consultants. Lawyers are likely to find that fewer issues will be seen as distinctively "legal" in character. Lawyers might be retained among a mix of advisors as a company formulates an environmental compliance program, for example, but the company is likely to give equal or even greater weight to the views of biologists, chemists and ecologists. Legal training may add weight to a lawyer's opinion, but lawyers who cannot provide non-legal insights as well may find their phone rings less often.

A practitioner's value to clients, in short, will have two dimensions - what she knows about a particular body of law and what she knows about a clients' industry or substantive concerns. A lawyer who tries back injury cases will need to know almost as much about backs as about tort law 
and trial practice. A securities lawyer will need to know as much about the economics of financial instruments, as about SEC regulation of them. A trade lawyer will need to know the culture of the countries in which her clients do business, and all lawyers will benefit from knowledge of some of the languages in which their clients - or their clients' suppliers and customers - work.

Some lawyers have resisted developing such non-legal expertise and even assert that professional rules urge them not to intrude into a client's substantive decisions. Likewise, I am not suggesting here that lawyers become directors of their clients or otherwise go into business with them. The issue is not about making or profiting from a clients' decisions; it is about having enough training and experience to understand and advise about those decisions.

Patent lawyers, for example, long have been required to be trained in a scientific or technical discipline so that they can prepare patent applications and evaluate and negotiate patent disputes. They are not expected to be inventors, but they would be less helpful to their scientist and inventor clients without the ability to speak and understand the technical language that both the clients and the patent examiners understand. Corporate mergers are similarly increasingly driven by issues of accounting and finance at least as much as by corporate and antitrust law.

Lawyers like to think they are good at lots of things, but experts in finance and accounting are equally likely to think they can look up the law themselves or hire less expensive lawyers to do it for them. Lawyers will continue to be called upon to be problem solvers, but they will be working in competition with a million fellow lawyers - as well as several million other consultants - to try to advise yet other lawyers who themselves have training relevant to a client's needs. Non-lawyer providers will make it a point to learn enough about the law relevant to their own activity that lawyers will not be able simply to bluff them into submission by asserting an exclusive right to explain legal issues. 
The lawyers who prosper will be those who can make themselves the best available go-to person in a combined law-and-substantive field and who market themselves accordingly. Blogging and use of networking sites will increasingly be attractive to lawyers who want to make themselves known to potential clients. To the extent someone else offers services of more value, clients will turn elsewhere. In any event, client needs will typically have little or no relation to subjects now traditionally tested on bar examinations.

For lawyers trained to think they are good at dealing with a wide range of legal issues, the prospect of becoming a mere consultant in a narrow specialty or mode of practice delivery may not initially be attractive. There is no inherent reason that a practitioner could not try to become competent in more than one field, but the ones in greatest demand are likely to be those who have specific, recognizable skills and who can work well with a team of lawyers and complementary professionals to meet a client's needs.

It seems to follow, then, that rather than living in an era like the golden age with a motto "nobody starves," future American lawyers are likely to face a world in which relatively few compete to be visible stars in the practice sky. Star lawyers will have big personal reputations and the demonstrated ability to manage teams of other lawyers and non-lawyers. Other practitioners whatever their training - are likely to serve on the stars' teams or as consultants to the stars, as they all the while seek to burnish their own star qualities. One effect of all this on people now in law school - or considering going to law school - is likely to be that even fewer will see the financial rewards that top graduates have come to expect as their due.

\section{The Future of the American Law Firm}

On the surface, the image of today's American lawyer becoming even more an individual specialist who markets his or her talent on the Internet might seem the antithesis of being part of a 
world-wide law firm. It does not follow, however, that if individual lawyers become more narrowly focused, law firms must become disappear or become small. Many specialized lawyers are likely to continue to practice in groups that resemble today's law firms, just as business consultants now practice in multi-specialty organizations, and the best law firms are likely to thrive. There are at least four reasons for that potential success.

First, law firms help lawyers manage the risk associated with being a narrow specialist. So long as a lawyer's expertise is widely needed, the lawyer may do well, but if needs of clients change, even able lawyers in a declining field will face problems. A booming economy may keep experienced corporate and commercial lawyers busy as clients seek to expand or go public. Bankruptcy lawyers get busier when the economy turns down. Deal lawyers keep the revenue flowing in good times, and to some extent pay the bankruptcy lawyers more than they deserve. Bankruptcy lawyers are expected to return the favor later.

Second, assembling lawyers into firms can also be useful to provide the sheer number of people that a large client may require for the kind of work the client needs done - closing a business deal, for example, or trying a major lawsuit. This so-called "project" work would overwhelm a solo practitioner or an in-house legal department, and while it would often be possible to form ad hoc teams of unrelated people for each new project, having groups already available from a single supplier may be significantly more convenient for a client.

Third, a firm allows lawyers to diversify the services they can provide for clients. This is another side of risk sharing. Because individual lawyers will tend to limit their practices and position themselves to be at the top of relatively small fields, it will take groups of lawyers with different areas of expertise to provide clients with the range of legal services any given matter might require. A firm that can provide what is sometimes called "one-stop-shopping" promises to be 
attractive to clients who want to retain a firm that is immediately ready to deliver help.

Fourth is the matter of marketing. Most lawyers do not like the prospect of advertising on late-night television. An Internet web site seem more respectable, but by far the best way for a lawyer to get instant recognition, respectability and the kind of credibility that will become even more important as clients have many professionals from whom to choose is likely to be to join a well-regarded law firm.

The challenge for many clients - even those with inside counsel - is likewise knowing which lawyers they can count on to provide good service. In an earlier era, consumers knew their service providers personally and could make their own assessment of trustworthiness and quality. Today, when dealings are distant and often under time pressure, it is brand names that provide the level of confidence and trust necessary to let transactions proceed. For many years, law firms ignored the importance of branding. Now, most national firms have no more than one or two words in their firm name and efforts to bring firm names to the attention of business travelers in airports, on television and in other commercial settings are ubiquitous. Lawyers realize that, when a client faces a significant question, it wants its advice to come from someone with instant credibility. It hard to know how significant brand names will be in clients' choice of counsel for all cases, but the growth of modern law firms in part reflects a belief that potential clients all over the world will find those names important.

But however attractive the current business model has been for big American firms, there are significant signs the model cannot survive without important changes. We often hear about changes in billing for legal services; that is too big an issue to take on here, and because it requires no regulatory change, clients and lawyers are likely to find that they can make changes in billing methods by themselves. 
The first change that does require regulatory action should be the recognition that few clients need only legal service. As lawyers become a species of business consultant, they will need to integrate their own services with those of other kinds of consultants. Some clients may choose to retain only one or a limited number of a firm's providers, but one of the reasons for having a firm will be to make it possible to provide each of the services a given client needs.

Several law firms already have expanded their range of services by adding law related services ranging from economic consulting to private investigation to financial management. Sometimes the services have been provided from within the firm; at other times, separate standalone or side-by-side entities have been created. A friend of ours who is an estate planner in Virginia, for example, has transformed himself and his firm into one giving wealth planning and give investment advice in addition to drafting wills and trusts. Lawyers in the firm have become licensed securities dealers and certified financial planners as well as lawyers in order to be able to deliver this total package. I believe other lawyers and firms are likely to take similar steps in their own areas of expertise.

A.B.A. Model Rule 5.4 currently prohibits a lawyer from sharing fees with, or forming a partnership with, a nonlawyer if any of the activities of their common work involves the practice of law. That is the provision that required our friend to himself become a financial planner instead of simply partnering with one. A decade ago, a report of the A.B.A.'s Multidisciplinary Practice Commission called for revisions in Rule 5.4, but they were defeated. The proposal had the misfortune to be considered by the A.B.A. around the time of the Enron scandal, and the concern most often expressed was that association with non-lawyers would lead lawyers into crooked behavior, never mentioning that Enron was itself advised several law firms, all operating under the current regime. The time has come to revisit the multidisciplinary practice decision. Multi-service 
practice organizations are not of interest only to corporate clients. Social service agencies that want to provide legal services as part of a package of services to the poor also have a stake in changing the present rules, and D.C. has permitted non-lawyer partners for many years with no loss of lawyer independence.

Further, the limitations on such organizations are ultimately self-defeating. Although U.S. lawyers are barred from participating in multi-disciplinary firms that deliver legal services in the United States, U.S. clients can often get the services from firms operating out of Great Britain or Europe. The American Bar Association has acted as though lawyers still operate in a world in which communication and travel are difficult. Clients know better. Regulatory regimes might properly continue to require competent service, protection of privileged information and avoiding conflicts of interest not waived by clients of the firm. Blanket prohibition of multi-service firms, however, should no longer be the rule.

The second needed regulatory change arises from a new concept likely to underlie most American law firms. Such firms have traditionally seen themselves as much like department stores, that is, a series of practice groups housed within a single firm. Even clients who seek out particular lawyers become clients of the firm as a whole. Each lawyer in the firm owes each firm client - even clients the lawyer has never met - the same duties owed by any other lawyer in the firm. Further, just as a Macy's clothing salesperson will try to get a customer to patronize Macy's for housewares needs, today's lawyers try to "cross-sell" clients of their own service, the services of other lawyers in the firm for their other needs.

That vision of a law firm will be under pressure. In the future, clients are likely to see professional service firms - including law firms - as less like department stores and more like shopping malls in which providers share a common location and overall name but each supplies its 
own services. For many years, the top law firms have competed to hire the brightest people possible, pay them top dollar, and employ them more-or-less as generalists to be used to handle matters in which the firms had a need for help. For reasons already discussed, there is good reason to doubt that such a strategy will work as well in the future.

If the dominant model for American law firms is to be one of practice groups built around star lawyers in particular fields, law firms will become little more than collections of service providers that offer particular services someone needs, when they need it. Under this model, if they wish to do so, corporate general counsel will retain less than an entire law firm for matters. They will assemble their own teams from multiple firms for a particular matter. Firms faced with this reality are likely to find themselves offering partial or "unbundled" services as an alternative to traditional legal representation. They might only try a case, for example, leaving discovery work to others. They might incorporate contract terms into a written agreement but leave negotiation of the deal to others. Unbundling is likely to be unsettling to lawyers who used to do an entire job, but such services will take maximum advantage of the lawyer specialization that seems inevitable.

The risks of law firms becoming "shopping centers," on the other hand, are substantial and will present serious problems for law firm managers. When a law firm does not have control over an entire matter, it may be hard to demonstrate later which provider's acts caused a client's loss. Even more unsettling, under such conditions, lawyers in a firm will be even more likely than today to be paid on a basis that they "eat what they kill" and try to operate independently of a central firm strategy and authority. When a lawyer knows she will get paid for fee-generating work she brings in - but that others will share the liability if the client turns out to be dishonest - the risk to firms will be enormous. 
In such an environment, clients as well as lawyers will have a stake in having professional standards reinforce efforts of law firms to establish a culture of ethical conduct by each of its lawyers and non-lawyers. Firm culture can make a difference. Young lawyers learn quickly that their future in the firm depends on how well they please their elders. Clients as well as lawyers will have a stake in having firms preserve the value of the reputation that is a firm-wide asset, but the challenge for managers will be to preserve that asset as firms have a less cohesive feel.

I think one of the steps that may assist firms to operate as a unit under the conditions I am predicting would be to get rid of the rules that regulate how lawyers may raise capital to finance their practices. Under current rules, lawyers who practice together in a firm may allocate revenue among themselves according to a partnership agreement or other contract. In a small firm, the senior partner who founded the firm might get $50 \%$ of all revenue, for example, while in other firms the revenues might be divided according to a formula that acknowledges who attracted cases as well as who did work on each.

What ABA Model Rule 5.4(d) says firms may not do today, however, is allow non-lawyers either to invest in - or share in allocation of legal fees earned by - a law firm. This prohibition both denies law firms the ability to raise potentially important form of capital and reduces the incentive a firm can give its members to help build the firm as an effective, ethical institution that will be attractive to outside investors. Further, if one accepts my first proposal to permit multi-service partnerships, the sale of stock in a law firm is but a short step. Non-lawyer participation in firm operation and management will itself involve recognition of the propriety of non-lawyers investing time and sharing the benefits of a law firm's potential success.

Others may think this proposal radical, but I do not. Nor do I propose it because law firms are capital hungry. Most firms are not capital intensive, and most will likely not want to pay 
investors the financial price investors would demand for the risk they would take investing in a law firm. That said, however, permitting firms to raise capital and create liquidity for members' own investments should not be a shocking prospect. The proposal should tend to keep firms working together in an environment otherwise tending to split them apart. In this sense, incentives created by this change to Rule 5.4(d) would benefit firms, firm clients and the public.

Third, the law regulating lawyers should be changed to permit covenants designed to slow lawyer movement in and out of firms. ABA Model Rule 5.6(a) should be amended to permit covenants designed to impose reasonable restrictions on a lawyer's changing firms. In the name of not restricting lawyer mobility, Model Rule 5.6 now permits a lawyer to leave her current firm with little or no notice, while at the same time trying to persuade clients to follow the lawyer to a new firm. The Rule likewise prohibits most kinds of financial penalties that firms might try to use to discourage such departures. The traditional argument against such restrictions has been that they violate a lawyer's professional independence. That made sense in a world in which most lawyers practiced alone anyway. Today, however, relatively few lawyers are independent; most work within some kind of firm or other organization and the financial viability of such firms and organizations depends on a reasonably stable number of participants.

Today, it costs law firms competing for top talent anywhere from $\$ 200,000$ to $\$ 500,000$ to bring a recent law graduate into the firm as an associate. The sum includes recruiting costs associated with a summer program after a student's second year, the tuition for a bar prep course, often a salary while the recent graduate studies for the bar examination, and the inevitable costs associated with writing off time spent on assignments the new lawyer did not fully understand. Nevertheless, at many firms, at least $40 \%$ of new hires have voluntarily resigned by the end of their $3^{\text {rd }}$ year in practice, hardly having made back the cost the firm spent to recruit them. 
One need not argue that lawyers must be yoked to the same firm forever to recognize that reasonable restrictions on departure can allow firms more financial security and flexibility in establishing their partnership rules and compensation structures. Law firms must contract for space, hire associates, and create incentives to develop the firm's reputation that only a degree of institutional stability permits.

Ultimately, firms are likely to have to convince young lawyers see that they have a future at the firm that will be attractive over a multi-year career. Doing so is likely to improve a firm's bottom line. In some cases, the solution may be part time work. In other cases, associates need to be given a sense they are growing in their practice, but requiring lawyers to spend a given period at a firm after joining it could be an important part of the process. In other employment cases, the law will not enforce restrictive covenants that are excessive in breadth or duration, but there seems no good reason to subject law firm covenants to greater restriction. Some courts have implicitly acknowledged this, recognizing that persons who make up a law firm should be capable of reaching arrangements appropriate to their situation. Conforming the rules to the decisions would be a third step in helping firms deal with the oncoming realities they will face.

\section{E. Impact of the Coming Changes on Legal Education}

The changing world facing American lawyers cannot help but impact the multi-billion dollar world of American legal education. At George Washington, for example - considering tuition, books, room \& board - each year is estimated to cost a student $\$ 66,300$, or a total of $\$ 200,000$ to earn the J.D. degree. That means that, each year, when our over 500 graduates pick up their diplomas, they have invested a total of $\$ 100$ million in their professional education. At other schools, the totals may be smaller, but at all of them, the sums represent real money, much of it borrowed. The question whether we are giving students what they think they are paying to receive 
is important today, but will be critical in the future.

In recent years, students have lined up to pay for the privilege of a legal education because a license to practice law long seemed the key to what many students see as a high-paying career. But if we are correct that the license is losing its significance and that the demand for lawyers as we traditionally think of them is likely to decline, the impact on legal education will be inescapable. Students are likely to want only the parts of a legal education that add value, that is, add enough to their understanding and skill to justify the tuition we require them to pay.

What lawyers need to know by they time they go into practice can be expressed in four broad categories - (1) how to analyze legal issues and "think like a lawyer," (2) enough substantive law to be able to place new knowledge into context, (3) concrete skills they can use to help improve a client's situation, and (4) enough non-legal understanding to see a client's problem from the client's point of view.

The first of these - learning to "think like a lawyer" - is what most law students find lifechanging. Lawyer-think involves learning how to read carefully, how to be sensitive to ambiguity, how to reason from a specific case to a general principle, how to see legal issues in a larger context of morality and social policy that will affect the long-term viability of particular principles. In addition, thinking like a lawyer involves developing the ability to narrow the focus of analysis on facts that are most immediately relevant to the matter at issue, and finally, how to keep abreast of changes in the law over the years of the lawyer's career.

The ability to employ these skills in varied situations helps explain why lawyers are valuable to clients and why the study and practice of law are satisfying to many lawyers. The important question for the future, however, will be what beyond training in the lawyer's version of critical thinking is required to produce people who can provide representation of the kind lawyers provide 
today. In the book on which this lecture is based, I go into the need for substantive legal training, skills training and understanding of non-legal issues, but in the interest of time I will skip over them here. What I will say is that the courses we traditionally teach and the three year period we take to teach them are and will be increasingly obsolete.

Almost forty years ago, in the early 1970s, an A.A.L.S. committee made some startling proposals that could have had dramatic effects on legal education and the legal profession as we know it today. The committee recommended making "legal education more functional, more individualized, more diversified, and more accessible." It proposed having law schools adopt a "standard curriculum" that could be begun by students after three years of college. The program could be finished in two academic years and would provide graduates with a grounding in core subjects and some "intensive instruction" in professional skills. An "advanced curriculum" would be available to students who wanted a third year of law training, but that year could also be completed in non-continuous units after leaving law school. An "open curriculum" would be available to non-professional students who simply wanted to learn more about law.

The proposal was imaginative and ambitious, but it was opposed by a number of law schools that foresaw a potentially fatal decline in their tuition revenue if they could not mandate that students stay for more than two years. For almost a century, the A.B.A. Section on Legal Education and Admission to the Bar has played the dominant role in law school accreditation, and ultimately, the at-risk schools persuaded the A.B.A. Section not to recognize a two-year program of instruction in its accreditation standards. Because students from an unaccredited program cannot be admitted to the bar in most states, no law school adopted the proposed ideas.

But the pressure to reduce the cost of legal education is likely to be even stronger in the future than it was in 1970. For at least the forty years since the A.A.L.S. report, the pressure in legal 
education has been entirely the other way. Accreditation standards established by the ABA have driven law schools toward homogeneity. Some schools exceed the standards by more than others, but the required model of legal education has been largely the same at all of them. My message is that the push toward homogeneity should end. The work of the ABA Section has been useful in getting some state legislatures and university leaders to provide new buildings and to improve the quality of law schools that in years past were not very good. In the future, however, few law schools will be able to do all things well and there is no reason most should even pretend to try. Large law schools may be able to be better in more fields than smaller schools will be, but all law schools will be best advised to concentrate on cutting costs, being strong in a few fields and training lawyers who seek the school's strengths.

Both the ABA's MacCrate Task Force in 1992 and the Carnegie Commission in 2007 have revisited the future of legal education and urged that law schools move in new directions. Ironically, however, the changes they proposed would take legal education in what I believe are largely the wrong directions. Originally set up to study a "gap" between law school and practice, the MacCrate Task Force report evolved into a study of the "educational continuum" over the course of a professional career. Noting that law schools had traditionally seen their role as to develop a student's analytic skills and leave other skills to be learned in practice, the Task Force said law schools should do more practical training before a student graduated. The Task Force eschewed an intention to affect law school accreditation standards or determine law school curricula, but the direction on both fronts in the years following the Task Force report has been an expansion of the number of clinical professors and clinical offerings in American law schools.

Pressure in the direction of education that mimics traditional practice has only increased with publication of the most recent Carnegie Foundation report in 2007. Its premise is that legal 
education has suffered from the desire of universities to have their students assume the "detached position of the theoretical observer" with respect to legal issues instead of "the stance of engaged practice." The practice-oriented stance has intellectual integrity, the authors assert, and from that stance, students can be trained for the task of exercising "judgment in action."

Citing new research about learning, the authors called for a return to the heretofore-largelyabandoned system of training lawyers by "apprenticeship," albeit this time in a university setting. "Experts" in a field based on their practice experience rather than their academic study can be assumed to have worked out systematic approaches to legal issues, the authors posit, and everyone can assume these experts know how to apply their knowledge in an academic context. The report concludes that law schools should focus on three kinds of "apprenticeship" - "cognitive or intellectual" such as that taught in traditional law school classes, "expert practice" taught by practitioners in small groups, and "identity and purpose" taught by exposing students to the community of law practitioners.

In perhaps the most extreme response to the Carnegie report, the Washington \& Lee School of Law has announced that its students will devote their entire third year in law school to "professional development through simulated and actual practice experiences." Ironically, no one seems to have observed that students could get similar exposure by working at real law firms and receiving a salary instead of being required to spend a third year paying law school tuition to pretend to do such work.

The Howrey firm and some others have proposed, by contrast, to offer an apprenticeship experience with a lower entering salary but mentoring and early client contact opportunities designed to lead to a long-term career. No one knows whether such programs will be as good as they promise, but under current A.B.A. regulations they could not be treated as an externship for 
third year students because only unpaid work may receive academic credit. I believe in volunteer public interest service as much as anyone, but the idea that it provides genuinely better practice training is nonsense. The Carnegie Commission presupposes there is something inevitable about training lawyers in a three-year, six semester program, and that the only question is how to occupy students during those required years. In my opinion, such nonsense is appalling.

A call for better practice training begs the questions raised in this lecture about what the practice environment will look like in which legally-trained persons will live and work. An education that might have prepared students adequately for work in the early $20^{\text {th }}$ century is not likely to be equally successful in the $21^{\text {st }}$. If this lecture is correct that yesterday's practice and ways firms operate are changing rapidly, increasing a student's exposure to old assumptions and to choices among homogeneous schools is likely to represent a waste of time and money.

I propose instead that law schools and universities again introduce legal training into the undergraduate program as they once did and as Europeans still do. Many undergraduates could profit from being able to think like a lawyer even if they never go on to get a professional degree. Then schools should make more advanced academic and skills training available to students who would leave at the end of what is now the second year and who I would allow to take a licensing exam and specialize in one of several areas of particular interest to individual clients. The third year would be offered to anyone who wanted more context or more specialized training.

\section{F. Conclusion}

One of the responses to the changes I have proposed will be that the suggestions are not "professional." There is not time now to discuss the history of and problems created by the concept of professionalism. Suffice it to say that while many of the characteristics attributed to professionals - integrity, loyalty, keeping confidences, and a commitment to serve the client effectively - 
represent highly praiseworthy traits to which any moral person should aspire, those characteristics are ultimately those of individuals, not groups. It is individual lawyers - and non-lawyers acting both alongside and in competition with lawyers - that we hope will act in ways traditionally called "professional."

Firms and law schools can - and some already have started to - make the transition to the changes world I am describing. A number of firms seem to be taking advantage of the economic slowdown to reexamine the business model on which they are based, and a number of law schools, including Harvard and Vanderbilt, are modifying their curriculum in significant ways. Firms and schools that see change and embrace its implications for them are likely to survive and prevail; as for others, I have some doubt.

We are in the last days of the American lawyer we once knew. We should pay homage to that model, but then bury it. At the end of the day, ignoring the changes lawyers face will not constitute a mark of professional courage. Failing to recognize the reality of the pressures I have tried to identify in this lecture, and needed changes like the ones I have proposed, are likely only to delay efforts to make our colleagues and graduates constructive contributors to the challenging world that lies ahead. 